\title{
nature
}

3 March 2005 Volume 434 Issue no 7029

\section{Why Harvard needs Summers}

The head of Harvard University leaves much to be desired in terms of tact and demonstrable respect for those who disagree with him. But the university should stick with him, at least for the time being.

$\mathrm{T}$ here are many reasons to argue that Larry Summers, the bluntspoken head of Harvard University, should step down. But there are more compelling reasons for the president of one of the world's premier academic institutions to remain in place than for him to pack his bags.

Summers' immediate troubles flared up in January after he made controversial comments suggesting that differences in intrinsic ability might partly explain why so few women reach top-tier positions in science. Time will tell whether his comments wreak serious damage on the institution's reputation and its ability to recruit female students and staff. But the resulting uproar tapped a vein of deep and broad staff discontent about Summers' governing style — discontent on which this publication reported earlier this year (see Nature 433, 190-192;2005). Anger peaked at two fiery staff meetings in February, one of which Summers described as "searing". But it now seems that he will be able to ride out the current storm.

The economist and former US Treasury secretary has brought a corporate management style to Harvard's decentralized and scholarly environment. Aggressive, argumentative and domineering are just a few of the words used to describe him by foes and fans alike. The onus is now on Summers to learn some tact and to show greater respect for the diverse and gifted scholars who drive his institution. At a recent faculty meeting, he pledged to listen to staff more and to temper his words and actions.

Summers' past actions don't inspire much confidence in this regard. Within months of taking over at Harvard in 2001, he became embroiled in an unseemly public row with Cornel West, the institution's best-known African-American academic, who subsequently departed for Princeton. And he provoked a backlash from academics who felt that he had failed to consult them sufficiently on ambitious plans for the university's expansion to a new campus in Allston, Boston.

Ultimately, however, Summers' presidency must be judged by his overall contribution to Harvard and by the academic advances it makes during his tenure. Many staff members, including scientists, believe that the positive contributions he has already made, and the changes he is planning, count for more than his controversial style or his public comments on women in science.

For one thing, Summers has become a champion of scientific research at Harvard. He wants the university to invest heavily in scientific facilities and to establish a better environment for interdisciplinary research. He wants greater collaboration and synergy between research groups and departments than some academics would naturally adopt. And he expects scientific institutions to form the core of the university's massive expansion into the Allston campus.

The success of these projects will not become clear for some time, but many of the researchers involved are brimming with enthusiasm. Even some of Summers' critics acknowledge that it is better to have a strong-minded president who makes bold decisions for the good of the university than a faint-hearted head lacking ambition. And should Summers resign in the current circumstances, it is highly unlikely that his successor would display the strong leadership skills that Harvard requires.

Summers, however, will need the active support of his staff if he is to drive positive change. Whether or not that support is forthcoming will become clear in the next few months. If it is, Harvard can prosper under Summers' leadership.

\section{In pursuit of balance}

\section{Sunbelt states that have boomed economically should eventually earn a larger slice of the research pie.}

Un $\mathrm{n}$ the past quarter-century, economic and political clout in the United States has shifted markedly towards the south and the mountain west. Yet research dollars remain heavily concentrated in other parts of the country (see page 10). This creates an imbalance that political leaders and university presidents in states such as Florida, Texas and Arizona are now working energetically to address.

When the existing structure of US research came into being after the Second World War, the lion's share of grant funding flowed to the most powerful universities of that era - almost all of them on the east coast, in the midwest and in California. Since then, the distribution of economic activity and population in the country has shifted. But the most powerful research departments are still concentrated in the same places.

To a large extent, that is as it should be. The greatest strength of the US system is its meritocracy, with grants distributed on the basis of a robust peer-review system. Another is its diversity: there are at least a dozen agencies that support significant amounts of university research. And the system has a third strength, commonly misdiagnosed as weakness: the occasional willingness of Congress to fund specific projects directly. Used selectively, this process corrects the natural tendency of research dollars always to accumulate in the same places. Over time, these strengths will fuel the growth of top-flight research in the sunbelt states. For governors such as Florida's Jeb Bush, such growth can't come quickly enough.

There are many ways to encourage it. The best place to start is perhaps by establishing a robust public university. Arizona has fared well in this regard. But the more fragmented systems in Florida and Texas have struggled to attain the status to which the third- and fourth-largest states in the union must aspire.

Then there's the 'big bang' approach, as exemplified by Governor Bush's plan to invest a cool half-billion dollars in a branch of Scripps Research Institute at Palm Beach. There is some scepticism about the likely benefits of this plan, with critics saying that too many regions are banking on biotechnology as an economic engine. But Scripps Florida is not without logic. The original Scripps in La Jolla, after all, laid the foundation of the University of California at San Diego - now a research powerhouse. It is surely right for Florida and other states to aim high, and to aggressively pursue a larger slice of the science pie. 